\title{
The Green Housing Privilege? An Analysis of the Connections Between Socio-Economic Status of California Communities and Leadership in Energy and Environmental Design (LEED) Certification
}

\author{
Roshan Mehdizadeh $^{1}$, Martin Fischer ${ }^{1} \&$ Judee Burr $^{1}$ \\ ${ }^{1}$ Civil and Environmental Engineering, Stanford University, Stanford, USA \\ Correspondence: Roshan Mehdizadeh, Civil and Environmental Engineering, Stanford University, 473 Via \\ Ortega, Stanford, CA 94305, USA. E-mail: roshanm@stanford.edu
}

Received: January 3, 2013 Accepted: March 28, 2013 Online Published: April 16, 2013

doi:10.5539/jsd.v6n5p37 URL: http://dx.doi.org/10.5539/jsd.v6n5p37

\begin{abstract}
This statistical analysis investigated the socio-economic patterns of current residential Leadership in Energy and Environmental Design (LEED) certification in California cities and towns. Specifically focusing on the LEED certification process, this analysis assesses the correlation between the percent of residential buildings with LEED certification in California places and the socio-economic characteristics of those places. The pre-analytic hypothesis was that wealthier cities and towns would have a greater number of LEED certified homes with higher levels of LEED certification.

The results of Pearson correlation testing using the statistical software R showed no statistically significant relationship between the total number of LEED certified homes or at any level of certification and the socio-economic characteristics of the places in question. One very influential factor in this finding is the lack of available data-of the 1466 places in California treated as distinct by the U.S. Census with available economic information, only 75 of them had at least one LEED certified home.

Another important factor is the role of community development organizations in constructing LEED certified homes. $99.9 \%$ of the affordable homes considered in this report were part of large developments (2458 out of 2460 affordable homes), $76 \%$ of market-rate homes (anything outside of the "affordable" category) were part of large developments (238 of 314 homes), and $97 \%$ of all homes considered (2696 out of 2774) were part of large developments. This analysis of LEED certified homes in California at the admittedly early stages of implementation raises further questions about whether the LEED program can function as a tool for the private homeowner and whether a process currently influenced largely by developers can serve the needs of communities and homeowners.
\end{abstract}

Keywords: energy and environmental design, certification, socio-economic, green building, affordable homes, community and real estate development

\section{Introduction}

The Leadership in Energy and Environmental Design (LEED) program was established in 1998 as "a voluntary, consensus-based national standard to support and validate successful green building design, construction, and operations" (ICF Consulting, February 2003). This national green building certification system was formed by the U.S. Green Building Council (USGBC) and is designed to offer third-party building certification and professional design guidelines and accreditation services (ICF Consulting, February 2003). LEED takes an "integrated design approach," which examines the potential of the site itself, water conservation, energy efficiency and renewable energy, selection of materials, and indoor environmental quality. Once certified, a building can be classified into one of four tiered levels of LEED certification: Certified, Silver, Gold, and Platinum. The LEED certification program requires more "green elements" for higher levels of green building certification, with platinum certification being the highest level. A building is awarded points based on the number of elements it includes, thereby determining its certification level. According to a report on green housing standards, higher levels of certification can include stormwater retention through landscaping, innovative wastewater technologies, reflective roofs, energy generating sources, personal comfort controls, certified woods, low-emitting materials, and advanced monitoring systems (ICF Consulting, February 2003). 
LEED for Homes is a particular LEED rating system for residential building projects. This program was officially launched in 2008, and it is intended to be a green building certification system for market-rate and affordable homes. At its earliest phases now in implementation, the LEED for Homes building program is designed for new construction projects, not home renovations (USGBC, 2012). According to the LEED Rating System Selection Guidance (USGBC, September 2011), this rating system is appropriate for low-rise residential buildings of 1-3 stories or mid-rise residential buildings of 4-6 stories. The U.S. Green Building Council defines a building as "residential" if it fits the definition of "a unit or series of units that each includes a cooking area (comprised of $\operatorname{sink}(\mathrm{s})$, cooking appliance(s), preparation space(s)) a bathroom, and a sleeping area". Communal living facilities may or may not be defined as residential, depending on the decision of the USGBC project team that is assessing the building (USGBC, September 2011). Builders or developers interested in participating in the LEED for Homes certification program must participate through a LEED for Homes Provider organization. There are six such organizations in California: Davis Energy Group, Earth Advantage, Energy Inspectors Corp., EnergyLogic, Guaranteed Watt Saver, and Sonoran (LEED for Home Providers, 2012). A LEED for Homes "Green Rater" must then provide onsite verification that the home meets LEED standards before the building can be certified. A list of 33 people across California certified as Green Raters is available on the LEED for Homes website (USGBC, 2012). As of 2009, 1,908 homes received LEED for Homes certification, and 9,667 registered their intent to seek certification. As of 2012, the list of LEED certified homes has grown to over 15,000 residences (USGBC, 2012).

LEED for Homes is also participating in the movement to increase the number of LEED certified affordable homes. In fact, the LEED Homes Committee has formed an expert Affordable Housing Working Group to monitor the LEED rating system and it's applicability to affordable homes, and recommend ways that LEED can meet the needs of the affordable housing market (USGBC, 2012). The goal of the Affordable Housing Working Group is to develop new practices, educational tools, and collaborative partnerships that will promote the growth of affordable LEED certified homes (USGBC, 2012). A LEED for Homes webinar series on affordable housing provides access to discussions of the LEED affordable housing program. As of October 2011, 49\% of certified LEED certified homes were affordable homes, and $63 \%$ of the homes certified in 2011 were affordable homes (Homes 202, 2011). Of the 2,774 homes in California considered in this analysis, 2,460 homes were affordable homes. Figure 1 shows California LEED certified homes considered in this analysis by project type.

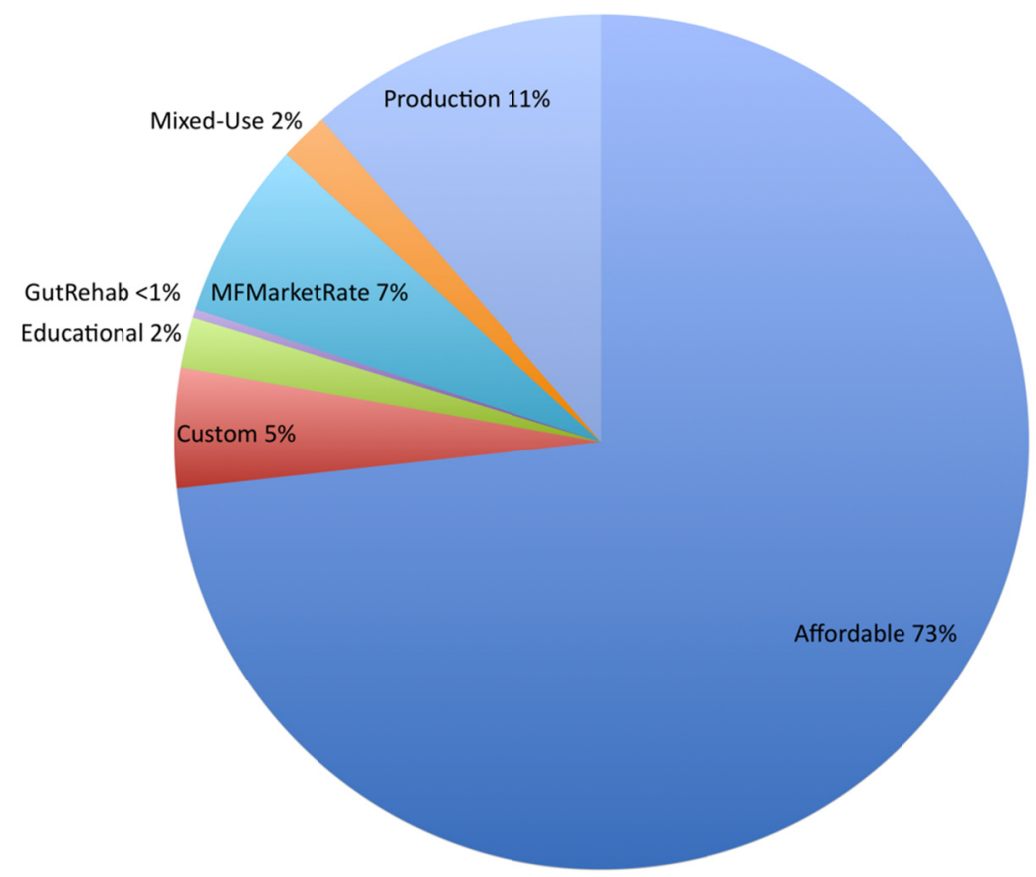

Figure 1. Most LEED certified homes in California are affordable homes 
Contrary to our the pre-analytic hypothesis that LEED residences would be disproportionately present in wealthy communities, the large number of residences classified by LEED as affordable indicates that LEED residences might be disproportionately present in low-income communities, as many of these homes are being built to be affordable. Since the goal of the program is to create affordable residential developments, low-income communities may be the beneficiaries of more LEED projects-providing reason to believe that there might be a negative correlation between a socio-economic factor like income level and the percentage of LEED certified homes in California communities.

Community-based development organizations play a large role in LEED certified home construction, especially due to the costs of registration, certification, and initial costs of implementing the green technologies necessary for certification. This is especially true because there are volume-based discounts available for registration of a large number of LEED housing projects. Registration of 10 or more single-family homes or a multi-family project with 50 or more units makes housing projects eligible for housing based discounts. Furthermore, the expenses associated with initial building or renovation costs of the LEED certification process plus the costs of certification and registration make building and certifying a residence out of reach for most individual homeowners. To have a project registered a fee of $\$ 450$ is applied for USGBC members and $\$ 600$ for nonmembers. The average certification fee is $\$ 2,000$, which varies depending on the project size (LEED for Homes, 2012). There are also more costs as the certification level increases, as the requirements become more stringent and call for more costly items; like solar panels or monitoring the energy performance of a building. At the gold and platinum levels of LEED certification, points are given for more costly technologies that have not become accessible or mainstream enough to be reduced in price; like solar cell technology or wind turbines.

Partially due to these costs associated with greening a home and getting LEED certification, community-based development organizations have played a notable role in developing affordable green residences. This has some clear benefits, like those outlined in a report on the costs and benefits of green affordable housing. These benefits include the idea that large housing developments are large and visible, thereby promoting green housing, $\mathrm{CBOs}$ can construct green residences cost-effectively, CBOs often have access to funds that can assist in green homes construction, and that $\mathrm{CBOs}$ often already have a connection with the communities in which they work (Bradshaw, 2005).

However, this involvement of CBOs also comes at the cost of direct engagement by homeowners with the green housing movement. More research is needed to examine the engagement of homeowners with residences that have been planned and constructed by a CBO. While CBO involvement can financially facilitate the ability of low-income residents to live in LEED certified homes, it is possible that CBO involvement can negatively affect community ownership and engagement with the green housing movement. Although this analysis does not answer this question, it is also important to ask whether residents experience all the benefits of living in a green home when that home is built as part of a development by a third party. There may be less tangible benefits, like engagement of homeowners and communities with the green movement, that are lost without direct involvement by community members in the certification process. It is known that green buildings provide positive outcomes for homeowners and represent an active way to engage in sustainable living practices (Bradshaw, 2005). Green homes reduce homeowner costs in the long run, lower energy usage, and provide increased comfort and a healthy living environment for the homeowner (Bradshaw, 2005; USGBC, 2012). If it is the case that it is disproportionately difficult for socio-economically disadvantaged members of the community to access LEED certified homes, such a lack of access would include a lack of access to benefits like lower household maintenance costs and living costs, greater comfort, and a greater ability to become involved in a more sustainable lifestyle. The methodology below will explain how we analyzed the relationship between LEED certified homes in California and the socio-economic characteristics of the cities in which they appear in order to answer empirical questions about the patterns of socio-economic characteristics of California places where green buildings appear.

\section{Methodology}

The aim of this analysis was to use LEED for Homes project information and U.S. Census data to determine the relationship between the occurrence and certification levels of LEED residences in California cities and towns and the corresponding socio-economic characteristics of the cities and towns in which buildings are constructed. 
Table 1. The socio-economic characteristics considered in this analysis

\begin{tabular}{cccc}
\hline Socio-Economic Factor & $\begin{array}{c}\text { Number } \\
\text { California Places }\end{array}$ & Mean & $\begin{array}{c}\text { Standard } \\
\text { Deviation }\end{array}$ \\
\hline Percent Unemployed & 1461 & $10.1 \%$ & $8.9 \%$ \\
Median household income (dollars) & 1461 & $\$ 61696.7$ & $\$ 31121.0$ \\
Mean household income (dollars) & 1444 & $\$ 77769.7$ & $\$ 45322.5$ \\
Median family income (dollars) & 1428 & $\$ 71073.3$ & $\$ 35611.3$ \\
Mean family income (dollars) & 1399 & $\$ 87751.2$ & $\$ 51633.7$ \\
Per capita income (dollars) & 1466 & $\$ 29713.5$ & $\$ 18436.5$ \\
$\begin{array}{c}\text { Percentage of all families whose income in the past 12 } \\
\text { months is below the poverty level (All families, percent) }\end{array}$ & 1460 & $10.5 \%$ & $12.2 \%$ \\
$\begin{array}{c}\text { Percentage of all people whose income in that past 12 months } \\
\text { is below the poverty level (All people, percent) }\end{array}$ & 1466 & $13.8 \%$ & $12.6 \%$ \\
\hline
\end{tabular}

As shown in Table 1, the different socio-economic characteristics considered in this analysis are percent unemployed, median household income, mean household income, median family income, mean family income, per capita income, percentage of families whose income in the past 12 months is below the poverty level, and percentage of all people whose income in the past 12 months is below the poverty level.

This analysis was aimed at answering the following questions:

1) Is there a statistically-significant correlation between the percent of LEED certified homes and the socio-economic traits of California cities and towns where these LEED certified homes occur?

2) Is there a statistically-significant correlation between different certification levels of LEED certified homes and the socio-economic traits of California cities and towns where these LEED certified homes occur?

3) Is there a statistically-significant correlation between "affordable" LEED certified homes and the socio-economic traits of California cities and towns where these LEED certified homes occur?

4) Is there a statistically-significant correlation between "non-development" LEED certified homes and the socio-economic traits of California cities and towns where these LEED certified homes occur?

To answer the above questions, we followed the methodology outlined below.

1) A list of LEED certified homes in California was taken from the USGBC LEED for Homes website (USGBC, 2012) and corresponding census information about California cities was taken from the 2006-2010 American Community Survey 5-Year Estimates on the American FactFinder website (ACS, 2006-2010). LEED data was categorized by California city or town according to the level of certification (certified, silver, gold, platinum) and socio-economic data consisted of mean and median household income, mean and median individual income, percent unemployment, percentage of families below the poverty line, and percentage of individuals below the poverty line.

2) The LEED housing data was normalized by converting counts of LEED residences in each place to percentages of residences in each place with LEED certification. In the LEED project directory, the LEED data was listed by "project", and projects often consisted of more than one LEED residence. The number of residences, not the number of projects was used in this comparison. The number of residences in each place was normalized by dividing the number of LEED residences by the estimates of number of households taken from the 2006-2010 American Community Survey.

3) R open-source statistical analysis software was used to analyze the data and look for correlations. A Pearson correlation test was run for the percent of LEED certified homes at each level of certification with each of the socio-economic traits of California cities and towns where these residential LEED projects occur. A Pearson correlation test was run for the percent of "affordable" LEED certified homes at each level of certification with each of the socio-economic traits of California cities and towns where these residential LEED projects occur. Finally, a Pearson correlation test was run for the percent of "non-development" LEED certified homes at each level of certification with each of the socio-economic traits of California cities and towns where these residential LEED projects occur. A home was considered 
not to be part of a larger development when a) there was a single home being constructed per project AND b) the single home was not part of a set $(>1)$ of projects built on the same date in the same place by the same builder. In these correlation tests, the null hypothesis that no correlation existed between the variables in consideration was rejected if the p-value was less than 0.05 , which indicates there is less than a $5 \%$ chance that random sampling would result in the observed correlation between the variables.

\subsection{Cleaning Up the Data}

In order to keep a consistent comparison with U.S. Census data, the California cities and towns without any reported economic information were not included in the analysis. See Appendix B for a list of the 55 California places not included (out of 1466 places total). None of these places had any LEED certified homes according to the LEED for Homes project list. Additionally, some places with LEED certified residential projects were not listed the same way on the LEED project directory as in the U.S. Census. For example, the U.S. census lists Los Angeles as one location, while some LEED projects were listed in affiliation with a specific suburb of Los Angeles. This happened in the case of eight Los Angeles suburbs and one suburb of San Diego. In these cases, the LEED projects associated with each suburb were added to the total number of projects for Los Angeles or San Diego, respectively. See Appendix B for lists of the suburbs grouped together in Los Angeles and San Diego.

\section{Results}

No statistically-significant correlation was found between the socio-economic characteristics of California places and the total number of LEED residences in each place in comparison with all levels or any specific level of LEED certification. Nor is there a correlation between socio-economic data and the percentage of affordable homes in each area at any certification level. Only when the data was restricted to those 78 homes that were not built as part of larger developments did a statistically-significant, positive correlation appear between the household and family income of the places these residences were built and the occurrence of these LEED residences. A home was considered not to be part of a larger development when a) there was a single home being constructed per project AND b) the single home was not part of a set $(>1)$ of projects built on the same date in the same place by the same builder.

However, it is important to note that, of the California cities and towns with available economic information in the 2006-2010 American Communities Survey, only 75 of 1466 places (5\%) had at least one LEED certified building. This was a severe constraint on the data analysis-most California places had zero LEED buildings, limiting the information we could use to draw a conclusion about the existence of a correlation between socio-economic characteristics of California places and LEED buildings present in those areas. This analysis should be built upon as more LEED residences are constructed, and more research should be done into the dynamics between homeowners, community-based development organizations, and affordable green residences to better understand the effects of LEED certification processes on socio-economically disadvantaged communities.

\subsection{All LEED Certified Homes}

There was no evidence of a significant correlation between the socio-economic factors of California places considered in this analysis and the number or level of LEED certified buildings in those places. See Appendix A for a plot of mean household income verses the percent of all LEED certified homes in California places.

\subsection{Affordable LEED Certified Homes}

Similarly, there was no correlation between the incidence of affordable LEED certified buildings and any pattern of socio-economic traits. Figure A.3 is an example of one plot. There is no statistical significance here or between any level of LEED certification and any of the socio-economic traits. See Appendix A for a plot of this relationship.

\subsection{Non-Development LEED Certified Homes}

In this final part of the data analysis, only LEED projects that were not part of large developments were considered and assessed in correlation with socio-economic characteristics of California places. Projects were considered to not be part of a development if a) there was a single home being constructed per project AND b) the single home was not part of a set $(>1)$ of projects built on the same date in the same place by the same builder. These restrictions were set to focus the analysis on smaller projects with a greater likelihood of specific homeowner involvement in the construction process. There were 78 projects (corresponding to 78 homes) out of the 558 projects ( 2774 homes) that were classified as "non-developments" according to this classification scheme. This is about $14 \%$ of projects and about $3 \%$ of homes considered. 
When only non-developments were considered, a more consistent and statistically significant correlation emerged between the socio-economic traits of the cities and towns where these projects appeared. This result has intuitive appeal - as projects that were not constructed as part of a development are seemingly more likely to be impacted by the socio-economic situation of the residents of a community. Below are two plots of data with a statistically-significant correlation.

Mean Household Income vs. Percent Non-Development LEED Homes in CA Places

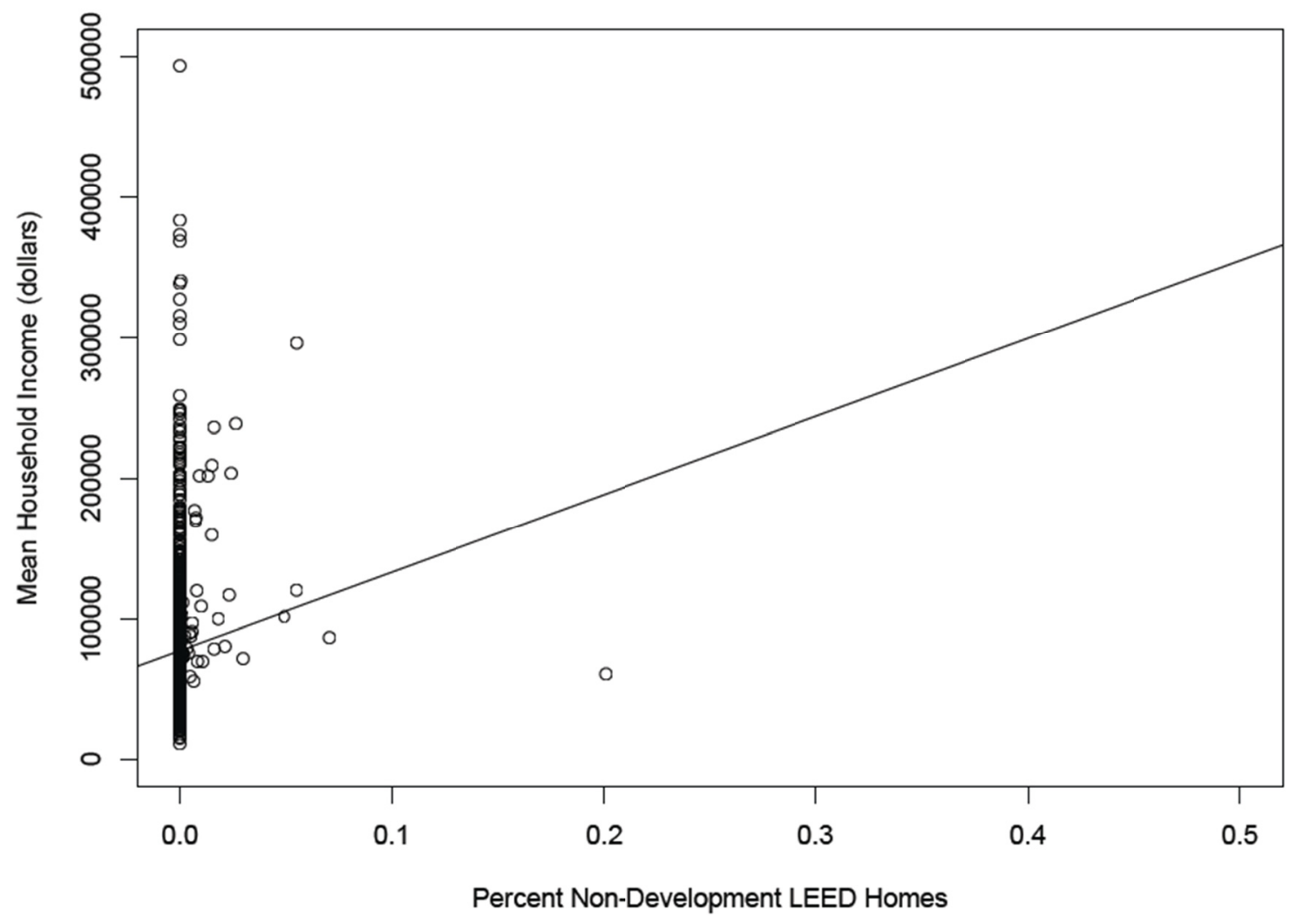

Figure 2. Mean household income verses percent of all non-development LEED certified homes in California Places (p-value: 0.002905 ) 
Mean Household Income vs. Percent Non-Development LEED Platinum Homes in CA Places

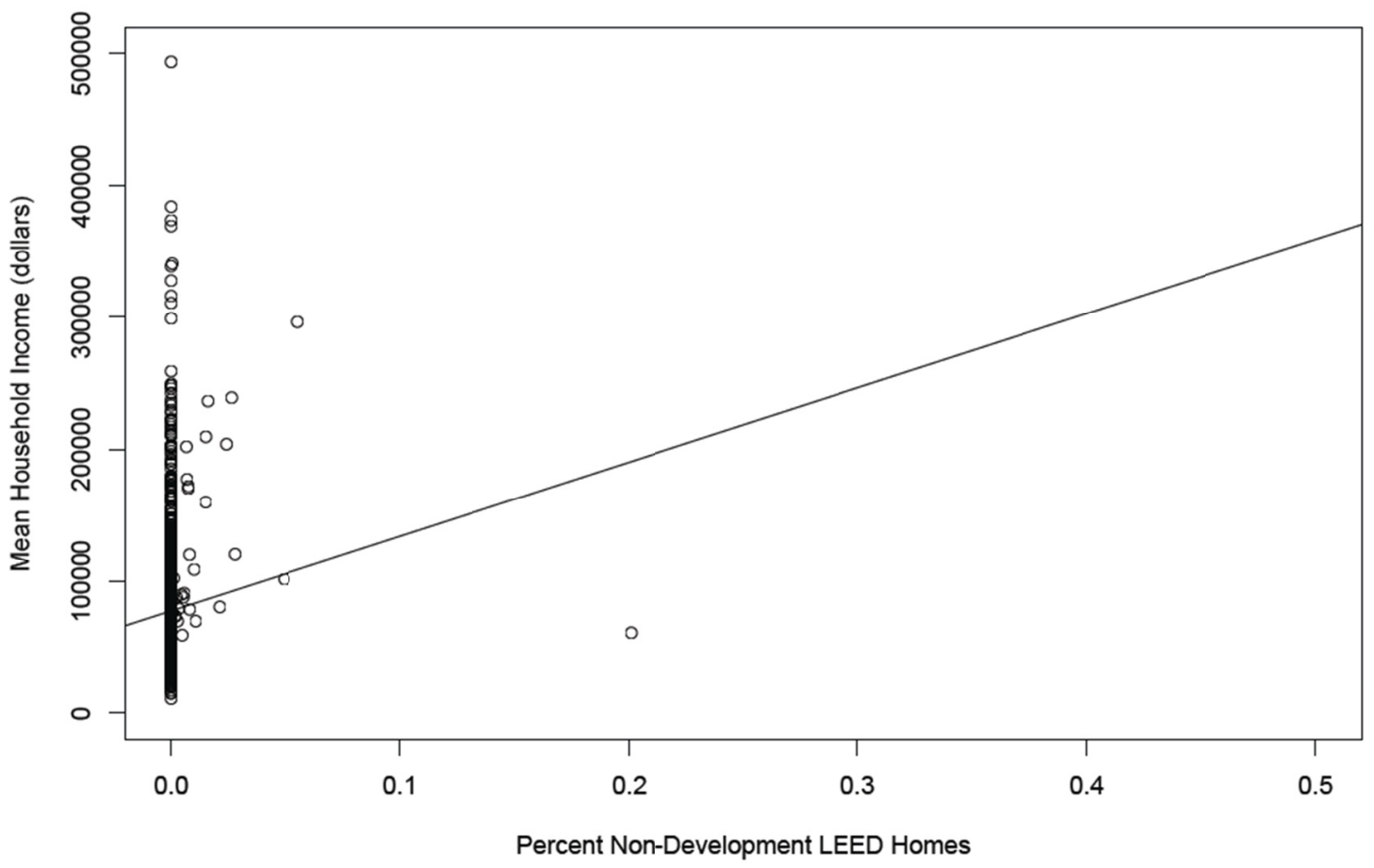

Figure 3. Mean household income verses percent of platinum non-development LEED certified homes in California Places (p-value: 0.005696)

These two examples show a positive correlation between the total number of LEED certified homes that are not developments and the mean household income in the California cities and towns in which they appear. There was also a statistically significant correlation between median family income and percent of LEED residences (all levels), median family income and percent of platinum LEED residences, median family income and percent of gold LEED residences, mean family income and percent of LEED residences (all levels), mean family income and percent of platinum LEED residences, mean family income and percent of gold LEED residences, and mean household income and percent of gold LEED residences. These relationships are all positive, indicating that the incidence of LEED certified buildings increases as income increases.

\subsection{Limitations of This Analysis}

It is still important to be wary of this statistical analysis due to the large number of data points equal to zero. Restricting the number of California places in a logical way to create a denser data set to analyze could help to study the relationship between LEED certified homes and community socio-economic characteristics more rigorously. However, further research into what characteristics of places are relevant to the occurrence of LEED residences is necessary to restrict cities in a logical way. For example, perhaps this kind of analysis could logically be restricted to cities of a certain population size or geographic area if LEED buildings are only constructed in places of a given area or population. Again, more research is needed to determine what these factors are.

\section{Discussion}

Although there are costs to obtaining LEED certification, most of this analysis found no correlation between the current incidences of LEED certified buildings in California and the socio-economic traits of the California cities and towns in which they occur. This seems to have been largely influenced by the lack of data in this relatively new program and the influence of large development projects in driving the occurrence of LEED certified buildings. The correlation between LEED certified non-developments and socio-economic data might indicate that with community development organizations playing a dominant role in green building construction, the socio-economic situation of residents themselves is less of a factor in green building construction. This could be taken as significant argument for the involvement of responsible community-based development organizations in the green affordable housing movement. However, questions remain about the impact of the CBO's on 
community and homeowner investment in green housing. As it stands, $99.9 \%$ of the affordable homes considered in this report were part of large developments (2458 out of 2460 affordable homes), $76 \%$ of market-rate homes (anything outside of the "affordable" category) were part of large developments (238 of 314 homes), and $97 \%$ of all homes considered (2696 out of 2774) were part of large developments. More research would be needed to understand whether there is a demand for green certification processes that are accessible to the homeowners in addition to CBO driven affordable housing developments or whether CBOs are effectively fulfilling needs for affordable green housing. There are compelling reasons to maximize community involvement and agency in green building processes. The result for less affluent cities that are unable to keep up with the green building movement will be that, because of their decision to not implement more costly green standards, they cannot compete in keeping and drawing the residents they need to build thriving communities. This issue is only exacerbated by the current economic downturn.

These concerns highlight the need to make green home certification accessible to all communities. One possible avenue to this level of accessibility is dependence on community-based development organizations to provide affordable green homes. This level of dependence could be seen as problematic, however, if it takes away from cities' ability to invest in green buildings on their own terms. Green building policies will impact the ability of local communities to self govern and make decisions locally, which is a fundamental component of a democratic government (Frug et al., 2010). As such, it is important to fully consider who should have the power to determine green building policies. As green building policies begin to mature and take root, greater awareness and analysis of their potential impacts is crucial.

Exactly what those impacts will be is thus far uncertain. Limits on the amount of data currently available obscure trends in the adoption of LEED certified buildings that will be strengthened as more projects are undertaken. Repeating this analysis on the national scale would be another enlightening research avenue designed to yield more information on these relationships. As more data becomes available, this analysis can be expanded upon to clarify the important relationship between the socio-economic status of communities and the accessibility of green buildings to those communities.

\section{References}

American Community Survey (ACS). (2010). American Fact Finder. U.S. Census Bureau. Retrived October 2, 2012, from http://factfinder2.census.gov/faces/nav/jsf/pages/index.xhtml

American Psychological Association. (1972). Ethical standards of psychologists. Washington, DC: American Psychological Association.

Anderson, C. A., Gentile, D. A., \& Buckley, K. E. (2007). Violent video game effects on children and adolescents: Theory, research and public policy. http://dx.doi.org/10.1093/acprof:oso/9780195309836.001.0001

Beck, C. A. J., \& Sales, B. D. (2001). Family mediation: Facts, myths, and future prospects. Washington, DC: American Psychological Association. http://dx.doi.org/10.1037/10401-000

Bernstein, T. M. (1965). The careful writer: A modern guide to English usage (2nd ed.). New York, NY: Atheneum.

Bjork, R. A. (1989). Retrieval inhibition as an adaptive mechanism in human memory. In H. L. Roediger III, \& F. I. M. Craik (Eds.), Varieties of Memory \& Consciousness (pp. 309-330). Hillsdale, NJ: Erlbaum.

Bradshaw, W., Connelly, E. F., Cook, M. F., Goldstein, J., \& Pauly, J. (2005). The Costs and Benefits of Green Affordable Housing. Cambridge, MA: New Ecology.

Cress, C. M. (2009). Curricular strategies for student success and engaged learning [PowerPoint slides]. Retrieved from http://www.vtcampuscompact.org/2009/TCL_post/presenter_powerpoints/Christine\%20Cress\%20-\%20Curr icular\%20Strategies.ppt

Driedger, S. D. (1998). After divorce. Maclean's, 111(16), 38-43.

FAQ. (2012). LEED for Homes Fequently Asked Questions. U.S. Green Building Council. Retrived October 15, 2012, from http://www.usgbc.org/ShowFile.aspx?DocumentID=3912

Frug, G. E., Richard, F. \& David, B. (2009). Local Government Law: Cases and Materials (West Publishing ed. 2010).

Gibbs, J. T., \& Huang, L. N. (1991). Children of color: Psychological interventions with minority youth. San Francisco, CA: Jossey-Bass. 
Gilbert, D. G., McClernon, J. F., Rabinovich, N. E., Sugai, C., Plath, L. C., Asgaard, G., ... Botros, N. (2004). Effects of quitting smoking on EEG activation and attention last for more than 31 days and are more severe with stress, dependence, DRD2 A 1 allele, and depressive traits. Nicotine and Tobacco Research, 6, 249-267.

Goleman, D. (2009). What makes a leader? In D. Demers (Ed.), AHSC 230: Interpersonal communication and relationships (pp. 47-56). Montreal, Canada: Concordia University Bookstore (Reprinted from Harvard Business Review, 76(6), pp.93-102, 1998).

Green Rater Locator. (2012). Retrived September 20, 2012, from http://www.usgbc.org/DisplayPage.aspx?CMSPageID=2528\#CA

Guignon, C. B. (1998). Existentialism. In E. Craig (Ed.), Routledge encyclopedia of philosophy (Vol. 3, pp. 493-502). London, England: Routledge.

HOMES 202: Numbers, Know How and Navigating LEED in Affordable Housing: Driving Smart Decisions in Green Affordable Housing. (2011, October 20). U.S. Green Building Council. Retrived September 20, 2012, from http://usgbc.peachnewmedia.com/store/seminar/seminar.php?seminar=9905

Klimoski, R., \& Palmer, S. (1993). The ADA and the hiring process in organizations. Consulting Psychology Journal: Practice and Research, 45(2), 10-36. http://dx.doi.org/10.1037/1061-4087.45.2.10

Kubrick, S. (1980). The Shining [Motion picture]. United States: Warner Brothers.

LEED for Homes. (2012). U.S. Green Building Council. Retrived March 10, 2012, from http://www.usgbc.org/DisplayPage.aspx?CMSPageID=147

LEED for Homes FAQ for Homeowners. (2012). U.S. Green Building Council. Retrived September 20, 2012, from http://www.usgbc.org/DisplayPage.aspx?CMSPageID=147

LEED for Homes Initiative for Affordable Housing. (2012). U.S. Green Building Council. Retrived March 10, 2012, from http://www.usgbc.org/DisplayPage.aspx?CMSPageID=147\#affordable_housing

LEED for Homes Providers. (2012). U.S. Green Building Council. Retrived November 2, 2012, from http://www.usgbc.org/DisplayPage.aspx?CMSPageID=1554

MacIntyre, L. (Reporter). (2002). Scandal of the Century [Television series episode]. In H. Cashore (Producer), The fifth estate. Toronto, Canada: Canadian Broadcasting Corporation.

McLuhan, M. (1970a). Culture is our business. New York, NY: McGraw-Hill.

McLuhan, M. (1970b). From cliche to archetype. New York, NY: Viking Press.

Mellers, B. A. (2000). Choice and the relative pleasure of consequences. Psychological Bulletin, 126, 910-924. http://dx.doi.org/10.1037/0033-2909.126.6.910

Postman, N. (1979). Teaching as a conserving activity. New York, NY: Delacorte Press.

Postman, N. (1985). Amusing ourselves to death: Public discourse in the age of show business. New York, NY: Viking.

Rating Selection Guidance. (2012). U.S. Green Building Council. Retrived September 15, 2012, from http://www.usgbc.org/ShowFile.aspx?DocumentID=6667

Semenak, S. (1995, December 28). Feeling right at home: Government residence eschews traditional rules. Montreal Gazette, p. A4.

Smith, April. (2003). Building Momentum: National trends and prospects for high-performance green buildings. U.S. Green Building Council, ICF Consulting. http://www.usgbc.org/DisplayPage.aspx?CMSPageID=77\#usgbc_publications 


\section{Appendix A:}

\section{Statistically Insignificant Relationships}

All LEED Certified Homes

Figure A.1 is a plot of mean household income of California places considered and the percent of LEED certified homes (at all levels) that have been constructed in those places. It is clear from the plot that most cities have zero LEED certified homes, some have a very small percentage of LEED certified buildings (less than $0.5 \%$ ), and that there are a few outliers with a larger, but still small, percentage of certified buildings. The p-value of the correlation test between these two variables is 0.4032 , clearly showing that there is not enough evidence to reject the null-hypothesis that there is no correlation between these two factors.

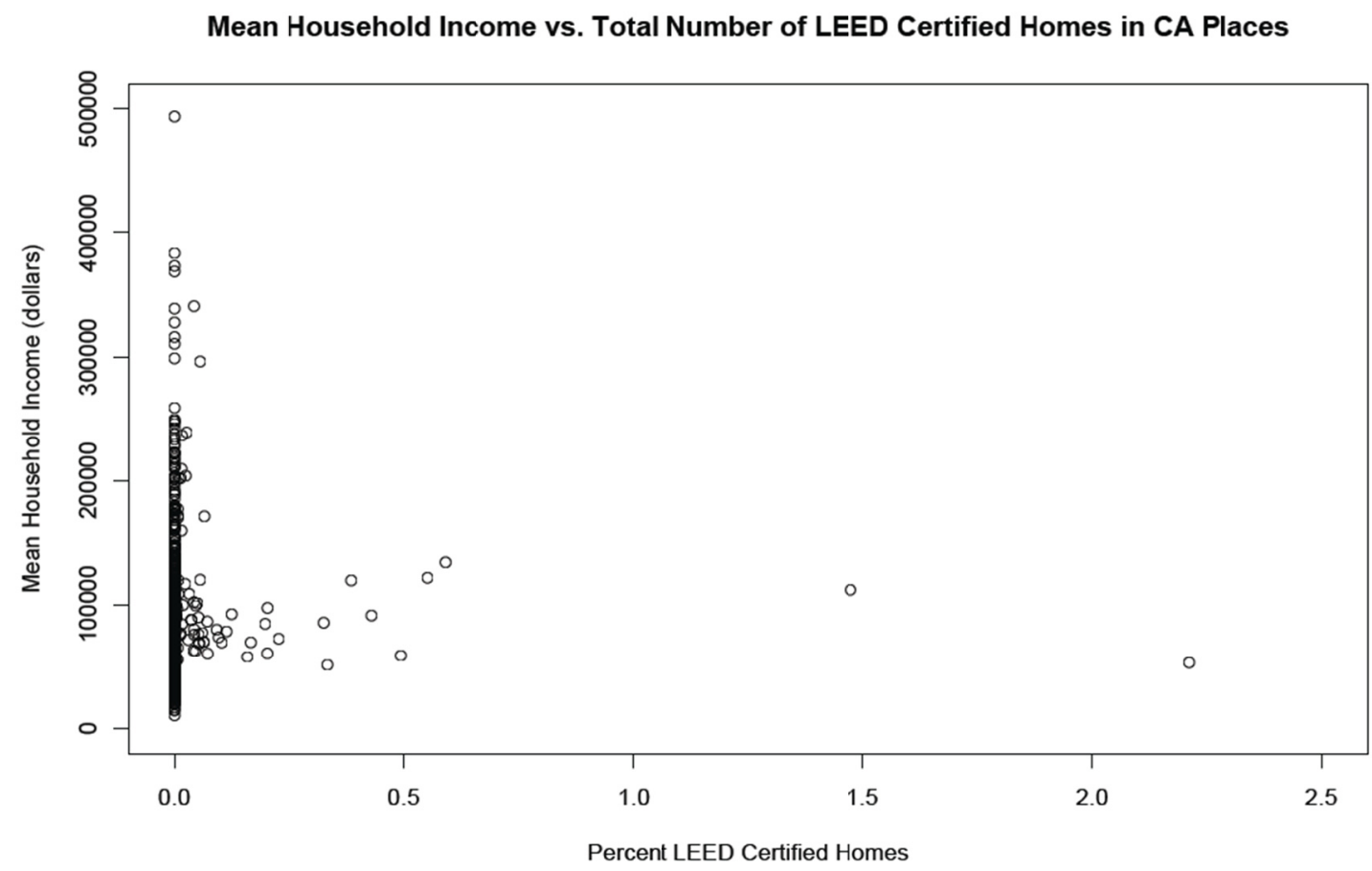

Figure A.1. Mean Household Income verses Percentage of All LEED Certified Residences per California Place $(p$-value $=0.4032)$ 
Most of the comparisons resulted in similarly statistically-insignificant correlations. Figure A.2 is the only correlation test that resulted in a p-value low enough to justify rejecting the null hypothesis of no correlation $(\mathrm{p}$-value $=0.02278)$. However, a look at the graph reveals that again a small number of outliers are driving the correlation. When the three values in question are removed, the correlation is not the same.

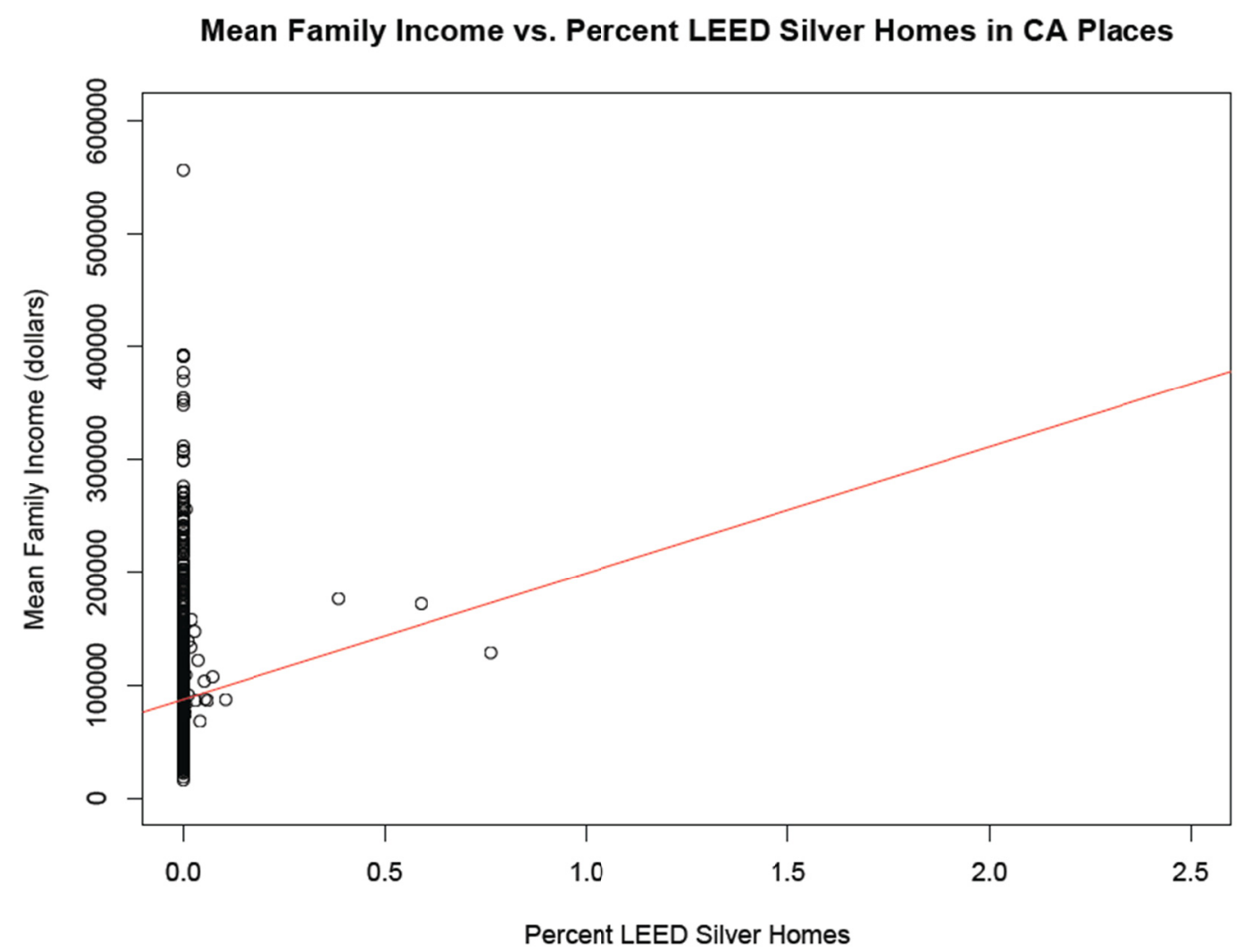

Figure A.2. Mean Family Income verses Percentage of LEED Silver Residences per California Place ( $\mathrm{p}$-value $=$ $0.02278)$ 


\section{Affordable LEED Certified Residences}

There was no correlation between the incidence of affordable LEED certified buildings and any pattern of socio-economic traits. Figure A.3 is an example of one plot. There is no statistical significance here or between any level of LEED certified affordable buildings and any of the socio-economic traits.

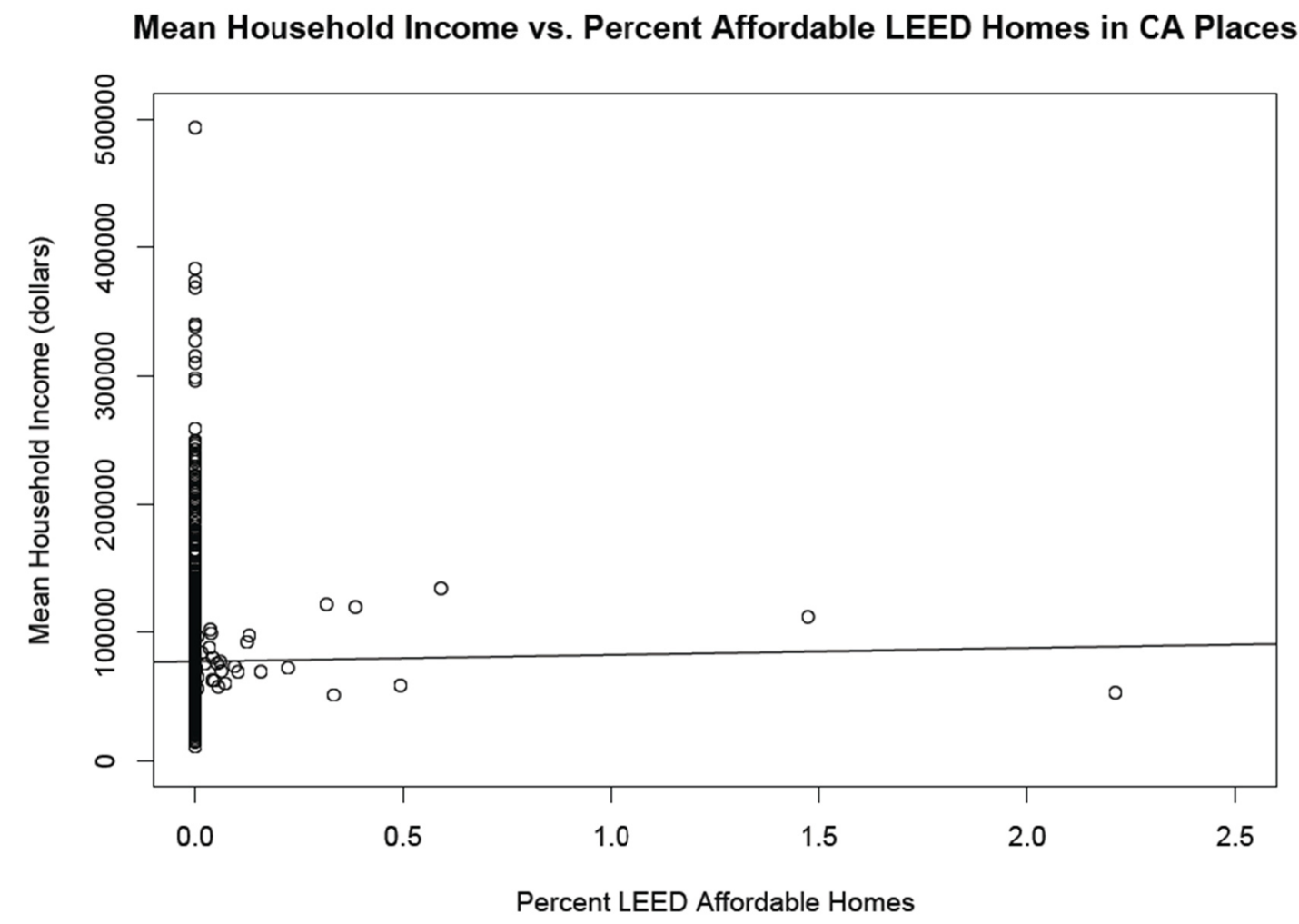

Figure A.3. Mean Household Income verses Percent “Affordable” LEED Certified Buildings at all Levels $(\mathrm{p}$-value $=0.7467)$ 
Appendix B:

California Places not included in this analysis, for lack of socio-economic information:

\begin{tabular}{|c|c|c|}
\hline Acampo CDP, California & Hartland CDP, California & Sattley CDP, California \\
\hline Almanor CDP, California & Hornitos CDP, California & Sequoia Crest CDP, California \\
\hline Aspen Springs CDP, California & Indian Falls CDP, California & Silver City CDP, California \\
\hline Blairsden CDP, California & Johnsville CDP, California & Spring Garden CDP, California \\
\hline Boulevard CDP, California & $\begin{array}{l}\text { Kennedy Meadows CDP, } \\
\text { California }\end{array}$ & Storrie CDP, California \\
\hline Buck Meadows CDP, California & Lake Davis CDP, California & $\begin{array}{l}\text { Strawberry CDP (Tuolumne County), } \\
\text { California }\end{array}$ \\
\hline Bucks Lake CDP, California & $\begin{array}{l}\text { Little Grass Valley CDP, } \\
\text { California }\end{array}$ & $\begin{array}{l}\text { Sugarloaf Mountain Park CDP, } \\
\text { California }\end{array}$ \\
\hline Canyondam CDP, California & $\begin{array}{l}\text { McClenney Tract CDP, } \\
\text { California }\end{array}$ & Sugarloaf Saw Mill CDP, California \\
\hline Caribou CDP, California & $\begin{array}{l}\text { McGee Creek CDP, } \\
\text { California }\end{array}$ & Tobin CDP, California \\
\hline Cedar Slope CDP, California & Milford CDP, California & Topaz CDP, California \\
\hline Clio CDP, California & $\begin{array}{l}\text { Mount Laguna CDP, } \\
\text { California }\end{array}$ & Trona CDP, California \\
\hline Clipper Mills CDP, California & Myers Flat CDP, California & $\begin{array}{l}\text { University of California Merced CDP } \\
\text { California }\end{array}$ \\
\hline El Rancho CDP, California & Paxton CDP, California & Valley Ford CDP, California \\
\hline Fish Camp CDP, California & Pearsonville CDP, California & Valley Wells CDP, California \\
\hline Floriston CDP, California & Pierpoint CDP, California & Warner Valley CDP, California \\
\hline $\begin{array}{l}\text { Franklin CDP (Sacramento County), } \\
\text { California }\end{array}$ & Posey CDP, California & Washington CDP, California \\
\hline Freeport CDP, California & Poso Park CDP, California & Whitehawk CDP, California \\
\hline Gold Mountain CDP, California & Prattville CDP, California & Wilsonia CDP, California \\
\hline
\end{tabular}

Graniteville CDP, California

Suburbs Grouped Under "Los Angeles" in our analysis:

Encino

Pacific Palisades

Panorama City

Playa Vista

San Pedro

Studio City

Toluca Lake

Venice

Suburbs Grouped under "San Diego" in our analysis:

La Jolla 